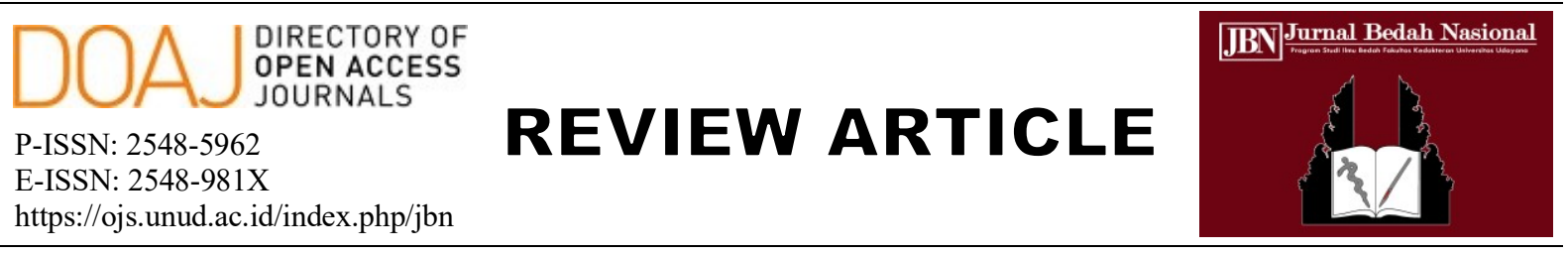

\title{
Rekonstruksi Pasca Ablasi Tumor Kepala dan Leher dengan Teknik Chimeric Flap
}

\author{
Medisa Primasari*, Sitti Rizaliyana \\ Departemen Bedah Plastik Rekonstruksi dan Estetik Universitas Airlangga/RSUD dr. Soetomo, Surabaya. \\ *Penulis korespondensi: medisaprimasari93@gmail.com.
}

\begin{abstract}
ABSTRAK
Keganasan pada kepala dan leher yang meliputi laring, kavitas oral dan orofaring, menempati urutan keenam jenis keganasan yang paling sering terjadi di dunia dan lebih dari $90 \%$ berasal dari sel skuamosa. Rekonstruksi pasca ablasi tumor menjadi hal yang menantang karena defek yang dihasilkan pasca ablasi tumor pada kepala-leher seringkali melibatkan struktur jaringan yang kompleks pada lokasi yang tidak berdekatan. Saat ini, chimeric flap menjadi pilihan dalam rekonstruksi defek pasca ablasi tumor karena flap ini mampu menyediakan variasi jaringan untuk defek multipel namun dengan satu tahap operasi. Beberapa pilihan chimeric flap yang dapat digunakan dalam rekonstruksi defek kepala dan leher adalah flap anterolateral thigh (ALT), flap sistem pembuluh darah subskapula, flap sistem pembuluh darah peroneal, flap temporoparietal, dan flap sistem pembuluh darah thoracoacromial.
\end{abstract}

Kata kunci: kanker kepala dan leher, defek kepala dan leher, rekonstruksi, chimeric flap.

DOI: https://doi.org/10.24843/JBN.2021.v05.i02.p04

\begin{abstract}
Head and neck cancer including larynx, oral cavities and oropharynx, is the sixth of the most common malignancy in the world, which more than $90 \%$ is squamous cells carcinoma. Reconstruction after tumor ablation is challenging because tumor ablation causes complex tissue structures defects in the distant location. Nowadays, chimeric flap is the choice in reconstruction of post-tumor ablation defect because it is able to provide tissue variation for multiple defects but with one stage of operation. Several choices of chimeric flap that can be used in the reconstruction of the neck head defect such as the anterolateral thigh (ALT) flap, the subscapula vascular system flap, the peroneal vascular system flap, the temporoparietal flap, and the thoracoacromial vascular system flap.
\end{abstract}

Keywords: head and neck cancer, head and neck defect, reconstruction, chimeric flap.

\section{PENDAHULUAN}

Kanker pada kepala dan leher menempati urutan keenam jenis keganasan yang paling sering terjadi di dunia dengan angka kejadian 630.000 tiap tahunnya dan lebih dari $90 \%$ merupakan karsinoma sel skuamosa yang berasal dari lapisan mukosa rongga mulut, orofaring, dan laring. ${ }^{1}$

Defek yang terjadi pasca ablasi tumor kepala dan leher seringkali melibatkan struktur jaringan yang kompleks pada lokasi yang tidak berdekatan, sehingga rekonstruksi merupakan hal yang menantang dan rekonstruksi segera dengan flap merupakan standar emas. ${ }^{2}$ Untuk mengembalikan fungsi dan tampilan pada defek yang kompleks dibutuhkan flap yang fleksibel dengan konfigurasi multiplanar, dapat berupa flap lokal, flap berpedikel, atau flap bebas. ${ }^{3}$

Penggunaan lebih dari satu flap lokal atau flap berpedikel dapat dilakukan, namun bukan menjadi pilihan utama. Operasi satu tahap menjadi pilihan utama dalam rekonstruksi, bahkan untuk defek yang multipel dan 
kompleks, karena tidak hanya menurunkan durasi operasi, namun juga mencegah kemungkinan komplikasi pasca operasi. ${ }^{4}$

Pilihan flap yang bisa menyediakan variasi jaringan untuk defek multipel namun dengan satu tahap operasi adalah chimeric flap yang bisa menyediakan dua buah atau lebih flap yang secara fisik tidak bersambung serta sumber pembuluh darah yang dimiliki berbeda namun tiap pembuluh darah berasal dari pembuluh darah yang sama sehingga anastomosis yang dilakukan hanya pada satu jenis pembuluh darah untuk menghidupi beberapa jenis flap pedikel. ${ }^{3,6}$

\section{CHIMERIC FLAP}

Pada rekonstruksi defek kepala-leher, banyak teknik yang sudah dikembangkan, namun, salah satu jenis flap yang bisa menyediakan variasi jaringan untuk defek multipel namun dengan satu tahap operasi adalah chimeric flap. ${ }^{6}$ Jenis flap ini didefinisikan sebagai flap yang terdiri dari dua buah atau lebih flap yang secara fisik tidak bersambung serta pedikel pembuluh darah yang dimiliki berbeda namun tiap pedikel bersumber dari pembuluh darah yang sama, sehingga anastomosis yang dilakukan hanya pada satu jenis pembuluh darah untuk menghidupi beberapa jenis flap pedikel. ${ }^{3}$ Salah satu contoh dari jenis chimeric flap adalah flap anterolateral thigh (ALT) yang dihidupi oleh pembuluh darah arteri femoral sirkumfleks lateral. Flap ALT (Gambar 1) dapat menyediakan kulit dan flap otot yang terpisah dalam blok-blok jaringan flap, namun terhubung melalui pedikel pembuluh darah yang sama. ${ }^{12}$

Perforator flap merupakan salah satu jenis dari chimeric flap. Pembuluh darah perforator diartikan sebagai pembuluh darah yang menghidupi kulit yang berjalan dibawah lapisan fasia profundus atau otot kemudian menembus fasia profundus (direkta kulit) atau otot (true perforator) untuk menuju ke lapisan kulit. ${ }^{3}$ Selain itu, konsep flap perforator diartikan sebagai flap dengan jaringan kulit atau otot dengan pembuluh darah yang menembus lapisan otot (muskulokutan) atau langsung menembus fasia (septokutan) (Gambar 2). ${ }^{13}$
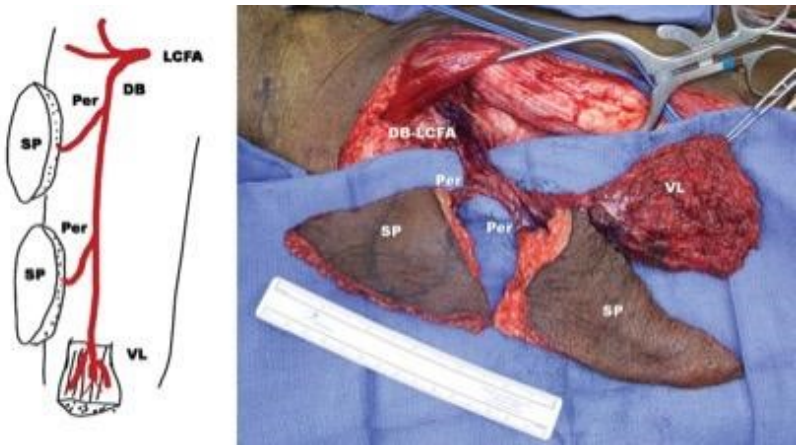

Gambar 1. Visualisasi dari jaringan yang dapat dihasilkan oleh ALT chimeric flap. LCFA, Lateral Circumflex Femoral Artery; DB; Descending Branch; Per, Perforator; SP, Skin Paddle; VL, Vastus Letralis. ${ }^{12}$

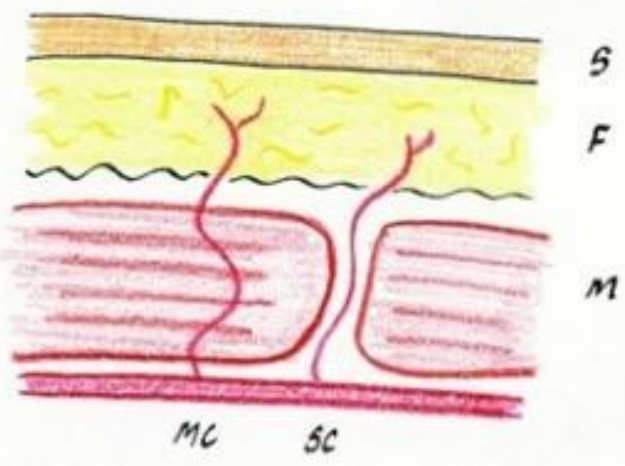

Gambar 2. Klasifikasi flap perforator. MC, pembuluh darah perforator muskulokutan yang menembus otot; $\mathrm{SC}$, pembuluh darah perforator yang menembus lemak atau septum inermuskular; S, Skin; F, Fat; M, Muscle. ${ }^{13}$

\section{REKONSTRUKSI BERDASARKAN AREA DEFEK}

\section{Rekonstruksi intraoral dan pipi}

Pada defek rongga mulut dan pipi yang kehilangan volume jaringan yang besar, flap dengan komposisi otot dan kulit merupakan komponen pengganti yang dibutuhkan. Flap dari forearm dapat digunakan pada defek luas pada intraoral dan pipi, namun flap ini tidak 
dapat mengembalikan ketebalan pada area tersebut. $^{14}$

Pada defek yang melibatkan defek unilateral atau bilateral pada lidah serta bagian mukosa pipi, penggunaan 3 island flap kulit hingga lapisan otot (muskulokutan) dari flap ALT dapat memenuhi seluruh kebutuhan jaringan. Flap bagian proksimal dan distal dapat digunakan untuk menutupi defek pada mukosa pipi, sedangkan bagian medial untuk lidah. ${ }^{4}$

\section{Keuntungan penggunaan ALT} dibandingkan dengan rektus abdominis yang sebelumnya sering digunakan adalah untuk menghindari permasalahan pada dinding perut. Namun kerugian dari penggunaan flap otot adalah ketebalan yang dimiliki akan berkurang akibat atrofi otot, terutama pasca radioterapi. Dalam rekonstruksi lidah, penggunaan flap dari regio abdomen atau deep inferior epigastric perforator (DIEP) dapat memberikan ketebalan yang mencukupi dari komposisi kulit dan jaringan subkutan tanpa mengorbankan otot perut. ${ }^{12}$

\section{Rekonstruksi oromandibula}

Defek luas pasca ablasi tumor pada oromandibular yang melibatkan hilangnya jaringan lunak dan tulang membutuhkan rekonstruksi yang kompleks, sehingga chimeric flap menjadi pilihan utama. ${ }^{15}$ Penggunaan sistem pembuluh darah peroneal memberikan banyak keuntungan dalam rekonstruksi defek oromandibular, karena anatomi yang konsisten, ketersediaan jaringan tulang yang memadai, flap kulit yang tipis dan lunak, pembuluh darah yang panjang, serta tidak mengorbankan jaringan donor. ${ }^{16}$ Flap kulit dan tulang atau flap otot dan tulang fibula, flap kulit serta flap kulit dan otot soleus/peroneus dapat diambil dari satu sumber pembuluh darah, yaitu arteri peroneal. Chimeric flap ini dapat menyediakan segmen tulang, otot, dan lebih dari 1 paddle kulit (Tabel 1). ${ }^{15}$

Tabel 1. Pilihan sumber donor chimeric flap untuk rekonstruksi defek oromandibula ${ }^{16,17,19,20,21}$

\begin{tabular}{|c|c|c|c|}
\hline Sumber Donor & Kondisi Flap Kulit & $\begin{array}{l}\text { Ketersediaan } \\
\text { Tulang }\end{array}$ & Ketersediaan Otot \\
\hline Sistem Peroneal ${ }^{16,21}$ & $\begin{array}{l}\text { - Dapat dibuat menjadi }>1 \text { paddle } \\
\text { kulit. } \\
\text { - Tipis dan lunak, bermanfaat untuk } \\
\text { menutup defek kulit superfisial atau } \\
\text { rekonstruksi intraoral. }\end{array}$ & $\begin{array}{c}\text { Ya } \\
\text { (fibula) }\end{array}$ & $\begin{array}{c}\text { Ya } \\
\text { (soleous dan } \\
\text { peroneous) }\end{array}$ \\
\hline $\begin{array}{l}\text { Sistem Sirkumfleksa } \\
\text { Skapularis }^{17}\end{array}$ & $\begin{array}{l}\text { - Dapat dibuat menjadi }>1 \text { paddle } \\
\text { kulit. } \\
\text { - Tebal, bermanfaat untuk menutup } \\
\text { defek yang membutuhkan volume } \\
\text { jaringan yang besar. }\end{array}$ & $\begin{array}{c}\text { Ya } \\
\text { (skapula lateral) }\end{array}$ & $\begin{array}{l}\text { Ya } \\
\text { (teres mayor, } \\
\text { latissimus dorsi, dan } \\
\text { serratus anterior) }\end{array}$ \\
\hline $\begin{array}{l}\text { Arteri Circumfleksa } \\
\text { Femoralis Lateral }^{19}\end{array}$ & $\begin{array}{l}\text { - Dapat dibuat menjadi }>1 \text { paddle } \\
\text { kulit. } \\
\text { - Tebal, bermanfaat untuk menutup } \\
\text { defek yang membutuhkan volume } \\
\text { jaringan yang besar. }\end{array}$ & $\begin{array}{c}\text { Ya } \\
\text { (krista iliaka) }\end{array}$ & $\begin{array}{l}\text { Ya } \\
\text { (rektus femoris dan } \\
\text { vastus lateralis) }\end{array}$ \\
\hline Forearm $^{20}$ & $\begin{array}{l}\text { - Dapat dibuat menjadi }>1 \text { paddle } \\
\text { kulit, namun terbatas karena } \\
\text { pembuluh darah perforator pendek. } \\
\text { - Tipis dan lunak, bermanfaat untuk } \\
\text { menutup defek mukosa intraoral }\end{array}$ & $\begin{array}{c}\text { Ya } \\
\text { (radius) }\end{array}$ & Tidak \\
\hline
\end{tabular}

Sumber flap lain untuk rekonstruksi dari batas skapula dengan pembuluh darah maksila atau mandibula adalah bagian lateral arteri sirkumfleksa skapularis. Dalam sistem 
subskapular, arteri subskapular bercabang arteri subskapular dan arteri sirkumfleksa menjadi 2 cabang utama, yaitu arteri femoralis lateral. (Gambar 3). ${ }^{19}$

thorakodorsal dan arteri sirkumfleksa skapularis. Flap yang berasal dari arteri sirkumfleksa skapularis dapat dimanfaatkan menjadi chimeric flap berupa flap kulit, flap otot (teres major, latissimus dorsi, dan serratus anterior) serta flap tulang skapula lateral. ${ }^{17}$ Dalam rekonstruksi defek oromandibula yang melibatkan defek jaringan yang kompleks dan luas, penggunaan sistem subskapular sangat bermanfaat. Jumlah jaringan yang melimpah pada sistem subskapular dapat dimanfaatkan untuk rekonstruksi tulang langit-langit, mukosa kavitas oral, atau defek kulit yang dapat menyediakan lebih dari satu flap kulit. ${ }^{18}$ Pada pasien dengan defek setengah bagian mandibula disertai dengan defek through and through pada jaringan lunak dilakukan rekonstruksi dengan chimeric flap dari pembuluh darah arteri sirkumfleksa femoralis lateral. Jaringan yang terlibat dalam rekonstruksi ini adalah krista iliaka (dari cabang asenden arteri femoralis sirkumfleksa lateral), flap kulit bagian proksimal untuk rekonstruksi bagian dalam, otot rektus femoris untuk mengisi dead space, serta flap kulit bagian distal untuk mengganti jaringan kulit luar. ${ }^{19}$

Walaupun cukup sering digunakan dalam rekonstruksi defek mandibula, namun kualitas dari tulang radius dianggap kurang sesuai untuk rekonstruksi defek mandibula karena tingginya angka fraktur dan ketersediaan tulang yang terbatas. Namun sebaliknya, kualitas dari flap kulit yang tersedia dari region forearm dianggap yang paling baik dibandingkan flap kulit dari alternatif donor lainnya karena tipis dan lunak, sehingga cocok untuk rekonstruksi defek mukosa intraoral. ${ }^{20}$

Dalam penelitiannya, Silva menunjukkan beberapa chimeric flap yang dapat menjadi pilihan sumber donor untuk defek oromandibula, yaitu flap dari arteri peroneal,

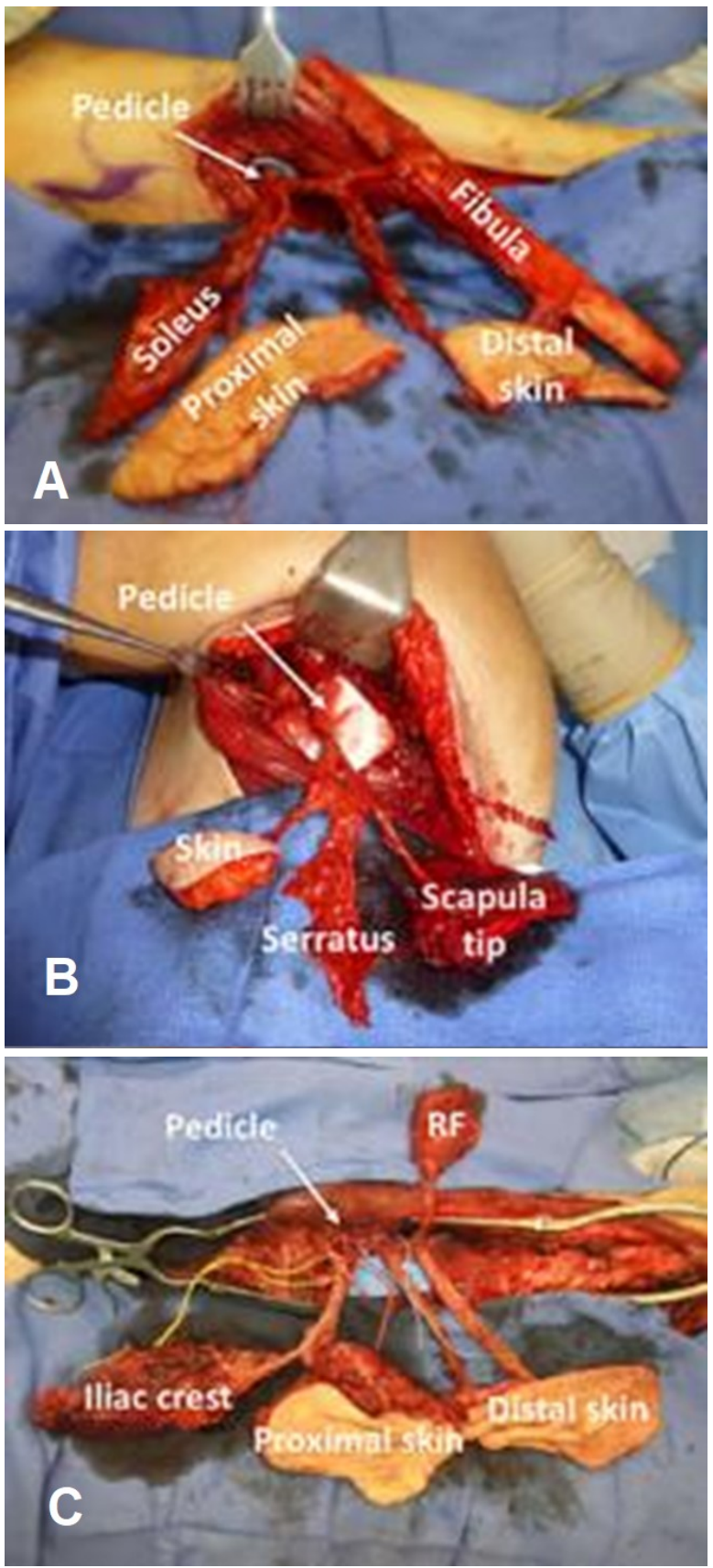

Gambar 3. Chimeric flap untuk rekonstruksi defek oromandibula. (A) Chimeric flap arteri peroneal. (B) Chimeric flap arteri subskapular. (C) Chimeric flap arteri sirkumfleksa femoralis lateral. RF, rektus femoris. ${ }^{19}$

\section{Rekonstruksi midface}

Fokus utama dari rekonstruksi area midface adalah mengembalikan struktur wajah, menyokong organ orbita, dan memisahkan 
kavitas mulut dan hidung. Pada defek yang melibatkan tulang maksila, penggunaan flap dari fibula, krista iliaka, dan rim skapula banyak digunakan. ${ }^{17}$

Chimeric flap yang berasal dari deep circumflex iliac artery (DCIA) sering juga digunakan untuk merekonstruksi defek pada maksila atau oromandibula karena kemampuannya untuk menyediakan komponen tulang dan kulit atau otot, serta mampu mencapai rehabilitasi oral dan support orbital yang baik. ${ }^{22}$ Chimeric flap lain yang dapat digunakan adalah flap dari temporoparietal. Struktur yang dapat diambil dari sistem ini adalah otot temporalis dan fasia temporoparietal dengan graft tulang kalvaria yang berasal dari pedikel arteri temporalis superfisialis (Gambar 4). ${ }^{23}$

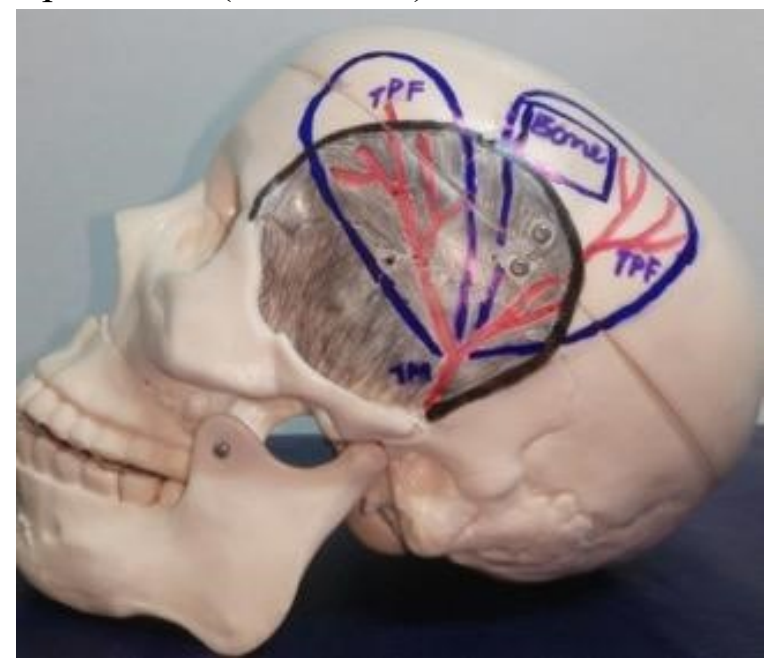

Gambar 4. Desain dari flap fasiokutan temporoparietal. TPF, Temporoparietal Flap; TM, Temporal Muscle. ${ }^{23}$

\section{Rekonstruksi hipofaring dan leher}

Reseksi tumor pada dasar mulut dan diseksi radikal dari leher menyebabkan defek kontur pada daerah hipofaring dan leher. Pada defek luas dan kompleks di area ini, penggunaan flap kulit atau muskulokutan dari ALT sangat menguntungkan karena flap dapat menyediakan dua blok flap fasiokutan atau miokutan. Flap yang berukuran besar dapat digunakan untuk merekonstruksi faringoesofagus, sedangkan flap yang lebih kecil untuk menutupi defek kulit bagian depan. $^{4}$

Walau demikian, penggunaan ALT tidak selalu bisa diandalkan dalam rekonstruksi defek tersebut, karena pada masing-masing individu tidak selalu tersedia lebih dari 1 pembuluh darah perforator pada flap ALT. Selain itu, penggunaan flap ALT membutuhkan keahlian dari operator dan tidak semua pasien dapat dilakukan operasi dengan teknik bedah mikro ini, terutama pada pasien dengan faktor-faktor komorbid. ${ }^{24}$ Maka dari itu, pilihan chimeric flap lain yang dianggap dapat memenuhi kebutuhan rekonstruksi adalah flap dari sistem arteri thoracoacromial. Arteri thoracoacromial terletak pada titik antara acromion dan prosesus xifoideus dengan garis midklavikula. Arteri ini memiliki 2 pembuluh darah perforator sehingga dapat menghasilkan dua paddle kulit untuk penutupan defek. Flap ini dapat menyediakan flap fasiokutan dan juga flap miokutan dari otot pektoralis mayor. Dalam kondisi kehilangan jaringan total pada faringesofagus, maka kedua flap digunakan untuk merekonstruksi defek. Namun pada kondisi near-circumference, maka flap fasiokutan digunakan untuk merekontruksi bagian dalam faringoesofagus, sedangkan flap miokutan otot pektoralis mayor digunakan untuk mengganti bagian anterior leher yang hilang (Gambar 5). ${ }^{24}$ 


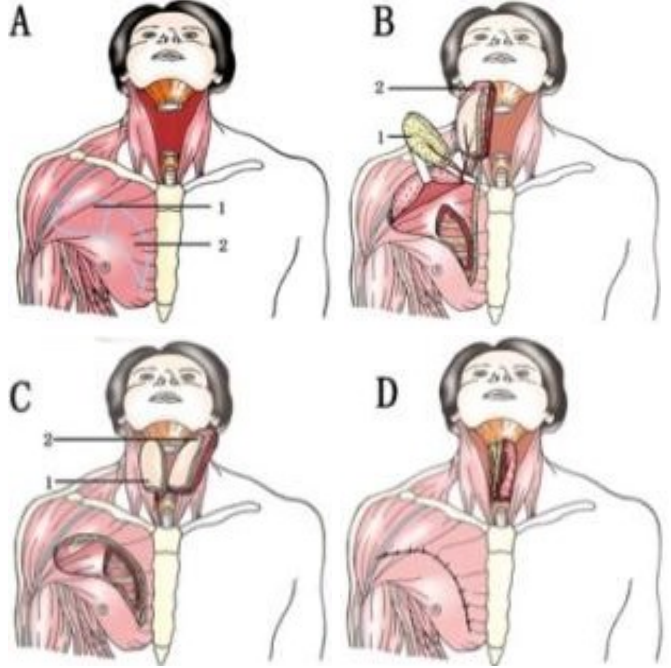

Gambar 5. Gambar skematis rekonstruksi faringoesofagus dengan flap sistem thoracoacromial. (A) Defek melingkar pada hipofaring dan kulit leher bagian depan serta desain chimeric flap arteri thoracoacromial. (B) Elevasi flap. (C) Pemindahan flap. (D) Flap sudah menutupi defek. (1) Flap thoracoacromial; (2) Flap pektoralis mayor. ${ }^{24}$

\section{SIMPULAN}

Dengan semakin meningkatnya angka kejadian kanker kepala dan leher di dunia, maka pengetahuan dan kemampuan ahli bedah dalam rekonstruksi defek yang dihasilkan pasca ablasi tumor juga harus semakin bertambah. Tindakan yang dilakukan pasca ablasi tumor diharapkan dapat memenuhi tujuan utama dari tindakan rekonstruksi, yaitu mengembalikan integritas, fungsi dan bentuk dari struktur komponen kepala dan leher.

Chimeric flap, baik sebagai free flap atau flap berpedikel, saat ini sering digunakan untuk rekonstruksi bagian kepala dan leher yang mengalami defek luas dengan jenis jaringan multipel pasca ablasi tumor, karena dianggap mampu menyediakan jumlah jaringan yang luas dengan komponen jaringan yang bervariasi dalam satu prosedur pembedahan. Saat ini, operasi satu tahap menjadi pilihan utama dalam rekonstruksi, bahkan untuk defek yang multipel dan kompleks. Hal ini tidak hanya menurunkan durasi operasi, namun juga mencegah kemungkinan komplikasi pasca operasi.
Penentuan dari sumber chimeric flap yang akan digunakan dapat dilihat dari luas, jarak antara defek dan komponen jaringan yang hilang. Jika yang dibutuhkan adalah komponen tulang, maka chimeric flap yang diambil dapat berasal dari arteri subskapula, peroneal, temporoparietal ataupun deep circumflex iliac. Namun, jika komponen utama yang dibutuhkan adalah jaringan lunak yang luas, maka sumber chimeric flap bisa didapatkan dari ALT, arteri subskapula, atau sistem thoracoacromial.

Pemahaman dari karakteristik masingmasing sumber chimeric flap, desain yang baik, serta teknik pengangkatan flap yang sesuai sangat diperlukan agar flap dapat dimanfaatkan dengan optimal dan kerusakan jaringan donor dapat diminimalisasi.

\section{PERNYATAAN}

Penulis tidak memiliki konflik kepentingan dengan pihak lain dalam penulisan ini.

\section{DAFTAR PUSTAKA}

1. Parkin DM, Bray F, Ferlay J, dkk. Global cancer statistics, 2002. CA Cancer J Clin. 2005;55:74-108.

2. Longo B, Nicolotti M, Ferri G, Belli E, Santanelli F. Sagittal split osteotomy of the fibula for modeling the new mandibular angle. J Craniofac Surg. 2013;24:71-4.

3. Prasetyono TH. Flap: Penuntun Dasar Ilmu Bedah Plastik. Jakarta: Sagung Seto; 2011.

4. Jiang C, Guo F, Li N, dkk. Multipaddled anterolateral thigh chimeric flap for reconstruction of complex defects in head and neck. PLoS One. 2014;9:e106326.

5. Weizman N, Gil Z, Wasserzug O, dkk. Surgical ablation and free flap reconstruction in children with malignant head and neck tumors. Skull Base. 2011;21:165-70. 
6. Hallock GG, Ahmadzadeh R, Morris SF. Classification of flap. Dalam: Wei F, Mardini S, penyunting. Flaps and Reconstructive Surgery, $2^{\text {nd }}$ ed. Edinburg: Elsevier; 2017. h. e7.

7. Johnson NW, Warnakulasuriya S, Gupta PC, dkk. Global oral health inequalities in incidence and outcomes for oral cancer: causes and solutions. Adv Dent Res. 2011;23:237-46.

8. Stenson KM. Epidemiology and risk factors for head and neck cancer up to date. UpToDate [serial online] 2018 [diakses 17 Desember 2019]. Diunduh dari:

https://www.uptodate.com/contents/epide miologyand-risk-factors-for-head-andneck-cancer.

9. Hayes DN, Van Waes C, Seiwert TY. Genetic Landscape of Human Papillomavirus-Associated Head and Neck Cancer and Comparison to TobaccoRelated Tumors. $J$ Clin Oncol. 2015;33:3227-34.

10. Bruce JP, Yip K, Bratman SV, dkk. Nasopharyngeal Cancer: Molecular Landscape. J Clin Oncol. 2015;33:334655.

11. Schiff BA. Overview of head and neck tumors. Merck Manual Professional Version. [serial online] 2018 [diakses 17 Desember 2019]. Diunduh dari https://www.merckmanuals.com/professi onal/ear,-nose,-and-throatdisorders/tumors-of-the-head-andneck/overview-of-head-and-neck-tumors.

12. Chana JS, Odili J. Perforator flaps in head and neck reconstruction. Semin Plast Surg. 2010;24:237-54.

13. Wei FC, Jain V, Suominen S, dkk Confusion among perforator flaps: what is a true perforator flap? Plast Reconstr Surg. 2001;107:874-6.
14. Liu ZM, Wu D, Liu XK, dkk. Reconstruction of through-and-through cheek defects with folded free anterolateral thigh flaps. J Oral Maxillofac Surg. 2013;71: 960-4.

15. Yang KC, Leung JKW, Chen JS. Doublepaddle peroneal tissue transfer for oromandibular reconstruction. Plast Reconstr Surg. 2000;106:47-55.

16. Cheng MH, Saint-Cyr M, Ali RS, dkk. Osteomyocutaneous peroneal artery-based combined flap for reconstruction of composite and en bloc mandibular defects. Head Neck. 2009;31:361-70.

17. Choi N, Cho JK, Jang JY, dkk. Scapular Tip Free Flap for Head and Neck Reconstruction. Clin Exp Otorhinolaryngol. 2015;8:422-9.

18. L'Heureux-Lebeau B, Odobescu A, Harris PG, dkk. Chimaeric subscapular system free flap for complex oro-facial defects. $J$ Plast Reconstr Aesthet Surg. 2013;66:9005.

19. Silva AK, Humphries LS, Maldonado AA, dkk. Chimeric vs composite flaps for mandible reconstruction. Head Neck. 2019;41:1597-604.

20. Disa JJ, Matros E. Mandible Reconstruction. Dalam: Thorne $\mathrm{CH}$, Gurtner GC, Chung KC, dkk, penyunting, Grabb and Smith's Plastic Surgery, $7^{\text {th }}$ ed. Philadelphia: Lippincott Williams \& Wilkins; 2014. h. 412.

21. Huang ST, Liu WC, Chen LW, dkk. Oromandibular reconstruction with chimeric double-skin paddle flap based on peroneal vessel axis for synchronous opposite double oral cancer. Ann Plast Surg. 2015;74 Suppl 2:S132-8.

22. Qing L, Wu P, Yu F, dkk. Sequential chimeric deep circumflex iliac artery perforator flap and flow-through anterolateral thigh perforator flap for onestage reconstruction of complex tissue 
defects. J Plast Reconstr Aesthet Surg. 24. Song D, Pafitanis G, Pont LEP, dkk. 2019;72:1091-9.

Chimeric thoracoacromial artery

23. Jose A, Nagori SA, Arya S, dkk. Chimeric perforator flap for one-staged temporopareital osteofascial and reconstruction of complex temporalis muscle flap; a novel method for pharyngoesophageal defects: A single unit the reconstruction of composite orbitoexperience. Head Neck. 2018;40:302-11. maxillary defects. $J$ Stomatol Oral Maxillofac Surg. 2019;120:250-4. 